Archive for

Organic Chemistry

Arkivoc 2019, part ii, 50-64

\title{
Synthesis of 2-organylselenopheno[2,3-b]pyridines and 1,6-diazaselenanthrenes via radical cascade reactions using tert-butyl nitrite
}

\author{
Gelson Perin, ${ }^{* a}$ Thiago J. Peglow, ${ }^{a}$ Ricardo H. Bartz, ${ }^{a}$ Roberta Cargnelutti, ${ }^{b}$ Eder J. Lenardão, ${ }^{a}$ \\ and Ricardo F. Schumacher ${ }^{* a, b}$ \\ ${ }^{a}$ Laboratório de Síntese Orgânica Limpa - LASOL, CCQFA, Universidade Federal de Pelotas - UFPel - P.O. Box \\ 354 - 96010-900, Pelotas, RS, Brazil \\ ${ }^{b}$ Departamento de Química, CCNE, Universidade Federal de Santa Maria - UFSM, 97105-900, Santa Maria, RS, \\ Brazil \\ E-mail: gelson perin@ufpel.edu.br; ricardo.schumacher@ufsm.br
}

Dedicated to Professor Lorenzo Testaferri in the occasion of his $75^{\text {th }}$ birthday

Received 06-14-2019

Accepted 08-25-2019

Published on line 09-16-2019

\section{Abstract}

We describe herein an alternative method to prepare 2-organylselenopheno[2,3-b]pyridines starting from bis(3-amino-2-pyridyl) diselenide and aryl- and alkylacetylenes in the presence of ${ }^{t} \mathrm{BuONO}$ in $\mathrm{CH}_{3} \mathrm{NO}_{2}$ as solvent. The reactions were conducted at $80{ }^{\circ} \mathrm{C}$ for 2 hours, and six selenopheno[2,3-b]pyridine derivatives were obtained in satisfactory yields, ranging from $10 \%$ to $41 \%$. Using the same conditions, but in the absence of the alkyne counterpart, three new 1,6-diazaselenanthrenes were obtained with yields ranging from $41 \%$ to $47 \%$. These compounds are unknown in the literature.

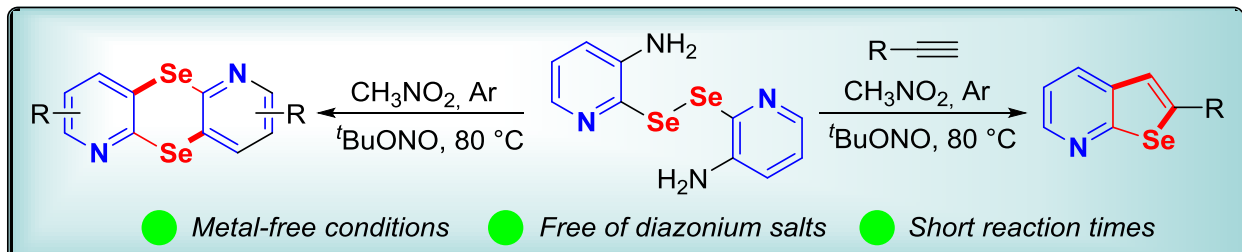

Keywords: Bis(3-amino-2-pyridyl) diselenide, 1,6-diazaselenanthrenes, selenopheno[2,3-b]pyridine, tert-butyl nitrite 


\section{Introduction}

Heterocycles are among the most important classes of natural and synthetic products, mainly due to their large application in the pharmaceutical industry. ${ }^{1}$ In special, the nitrogen-based heterocycles are the most significant structural components of pharmaceuticals, and analysis of database of U.S. FDA approved drugs made by Vitaku and coworkers in 2014 indicates that 59\% of unique small-molecule drugs contain a nitrogen heterocycle nucleous, being piperidine and pyridine the first and second most common ones. ${ }^{2}$

On the other hand, chalcogenophenes are five-membered heterocycles containing a chalcogen atom on its structure, which are widely found in pharmacological active compounds ${ }^{3}$ and new functional materials. ${ }^{4-6}$ For example, a Se-analogue of raloxifene was described by Arsenyan and coworkers as a promising antiproliferative agent for the treatment of breast cancer. ${ }^{7}$ A method for the preparation of benzoselenophene derivatives of milfasartan and eprosartan was described by Staples and coworkers, which have evaluated their $\mathrm{AT}_{1}$ receptor antagonist properties, showing as promising candidates for new antihypertensive drugs (Figure 1-A). ${ }^{8}$ Among chalcogenophene fused heterocycles, Gao and coworkers described a thiophene fused pyridine as a DRAK2 inhibitor, being a promising drug for the treatment of autoimmune diseases (Figure 1-B). ${ }^{9}$

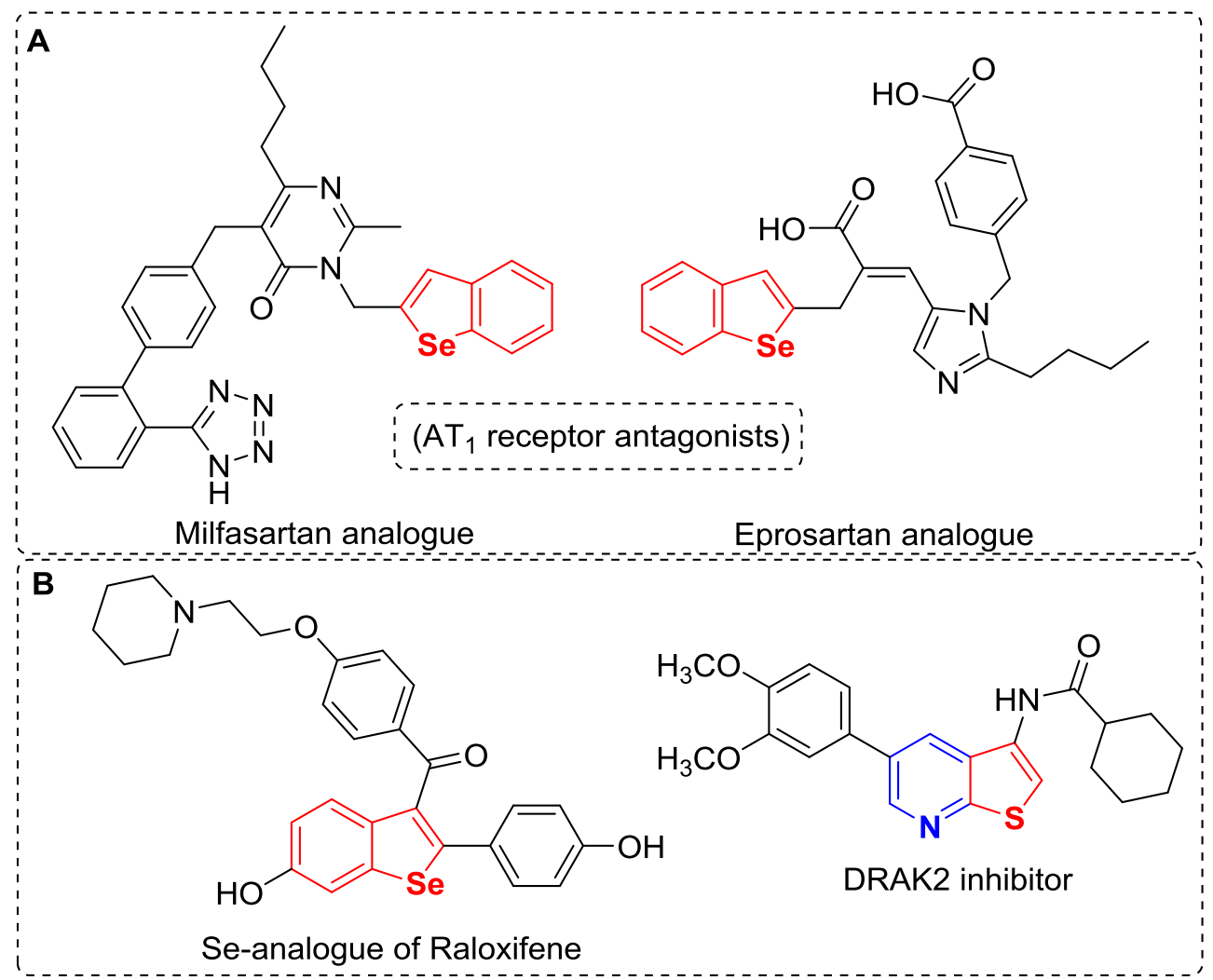

Figure 1. Molecular structure of Milfasartan, Eprosartan and Raloxifene analogues.

In addition, selenophenes and their benzo derivatives have been used as scaffolds for diverse biologically active compounds, ${ }^{10-11}$ in the synthesis of porphyrin analogs ${ }^{12}$ and in materials due to their properties as organic semiconductors, which showed potential as organic field-effect transistors (OFET's) or organic lightemitting diodes (OLED's), ${ }^{13-16}$ among other synthetic applications. ${ }^{17-18}$ Thus, due to their importance, many versatile and efficient methods have been published describing their preparation, including the use of 
diazonium salts and alkynes under iron ${ }^{19}$ or gold catalysis, ${ }^{20}$ the reaction of gem-dibromoalkenes, ${ }^{21-22}$ the $^{27}$ platinum-catalyzed annulation, ${ }^{23}$ the electrophilic cyclization of $o$-selanyl-ethynylbenzenes, ${ }^{24-26}$ and so on. ${ }^{27-29}$ When we turn attention to selenophene fused pyridine, to our knowledge, its first synthesis was reported by Wright and Corbett in $1993 .^{30}$ In that work 2-phenylselenopheno[2,3-b]pyridin-3-ol was obtained by the cyclization of 2-(benzylselanyl)- $N$-phenylnicotinamide in the presence of potassium tert-butoxide in DMF (Scheme 1-A). More recently, $\mathrm{Wu}$ and Yoshikai reported the annulation of (E)-3-(dec-5-en-5-yl)-2iodoquinoline using selenium powder, base and copper catalysis to produce different selenopheno[2,3b]pyridine derivatives (Scheme 1-B). ${ }^{31}$ Arsenyan described in 2016 the reaction between 3-heptynylpyridine and $\mathrm{SeBr}_{4}$ [prepared in situ by dissolving $\mathrm{SeO}_{2}$ in $\mathrm{HBr}_{(\text {conc) }}$ ] to produce 3-bromo-2-pentylselenopheno[2,3b]pyridinium hydrochloride (Scheme 1-C). ${ }^{32}$ Mhetre and coworkers documented the synthesis of ethylselenopheno[2,3-b]pyridine-2-carboxylate through the annulation of 2-(alkylselanyl) nicotinaldehyde under basic conditions (Scheme 1-D). ${ }^{33}$ More recently, in 2018, Sonawane and coworkers reported an efficient methodology to prepare a range of homologous selenopheno[2,3-b]quinoline derivatives via an iodocyclization reaction using 2-(methylselanyl)-3-(alkynyl)quinolines (Scheme 1-E). ${ }^{34}$

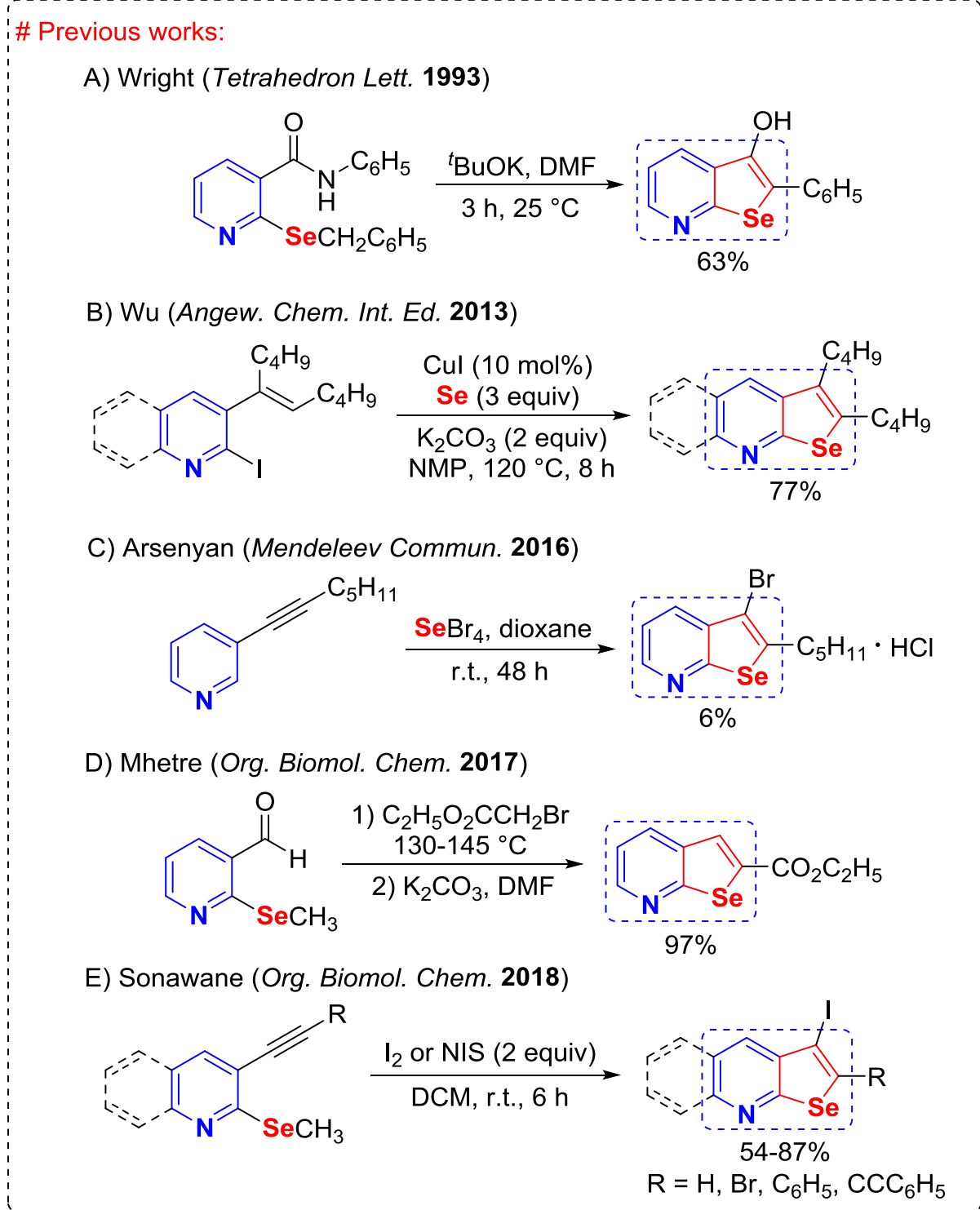

Scheme 1. Synthesis of selenopheno[2,3-b]pyridine derivatives and homologous. 
Our group has been dedicated to developing new synthetic methodologies to prepare pharmacologically promising organochalcogen compounds. Recently, we reported the preparation of bis(2-pyridyl) diselenide derivatives and their antioxidant and anticholinesterasic activities. ${ }^{35}$ Based on our previous findings and in those from Zang and coworkers, ${ }^{36}$ we hypothesize that these compounds could be ideal starting materials to synthesize fused selenopheno[2,3-b]pyridines by the reaction with terminal alkynes in the presence of a nitrosating agent (Scheme 2).

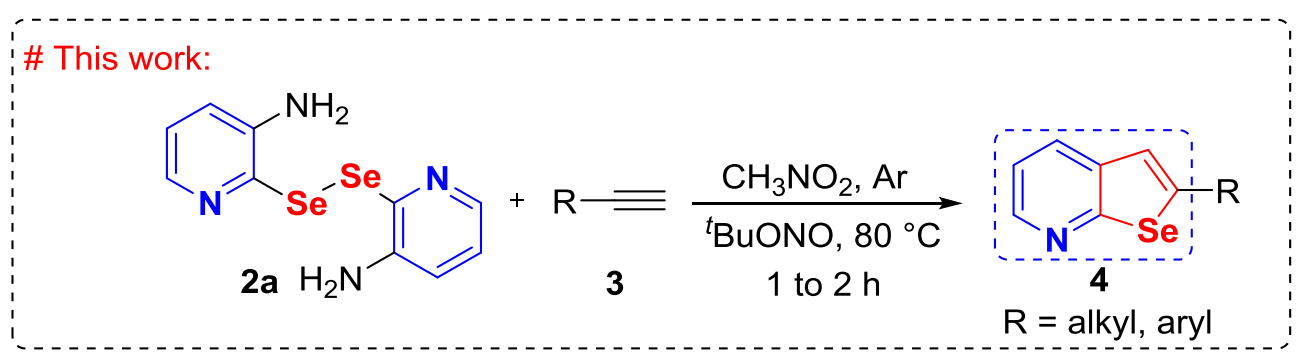

Scheme 2. General scheme of the present work.

\section{Results and Discussion}

Initially, we selected different 2-alkylselanyl-pyridin-3-amine $\mathbf{1} \mathbf{a}-\mathbf{b}$ and bis(3-amino-2-pyridyl) diselenide $\mathbf{2 a}$ as substrates to react with phenylacetylene 3a using tert-butyl nitrite as a nitrosating agent under argon atmosphere to evaluate our hypothesis. Still, to establish the best reaction conditions, other variables were also studied, such as the nature of the solvent and the temperature of the reaction, and these results are summarized in Table 1. For the synthesis of the starting materials $\mathbf{1}$ and $\mathbf{2}$ we followed the procedures recently described by us. ${ }^{35}$

Thus, our preliminary experiment consisted in stirring a mixture of $0.25 \mathrm{mmol}$ of 2 -(methylselanyl)pyridin-3amine $1 \mathrm{a}, 0.75 \mathrm{mmol}$ of phenylacetylene $3 \mathrm{a}$ and $0.5 \mathrm{mmol}$ of tert-butyl nitrite in nitromethane $(1.0 \mathrm{~mL})$ as solvent at $80{ }^{\circ} \mathrm{C}$ for $2 \mathrm{~h}$ under argon atmosphere. Under these conditions, the desired 2phenylselenopheno[2,3-b]pyridine 4 a was obtained in $27 \%$ yield (Table 1 , entry 1 ). Due to the low yield, we decided to employ 2-(butylselanyl)pyridin-3-amine $\mathbf{1 b}$ as starting material, which gave the expected product in only $23 \%$ (Table 1 , entry 2 ). To our satisfaction, when the reaction was performed directly with bis(3-amino-2pyridyl) diselenide $\mathbf{2 a}$, the product $\mathbf{4 a}$ was obtained in $40 \%$ yield, almost the double that using selenides $\mathbf{1 a}$ and $\mathbf{1 b}$. This outcome represents a reduction of waste production and time consuming (Table 1 , entry 3 ).

Furthermore, it was obtained $11 \%$ of 1,6 -diazaselenanthrene $\mathbf{5 a}$, an unpublished product so far. Thus, aiming to increase the reaction yield, bis(3-amino-2-pyridyl) diselenide 2 a was chosen as standard starting material and other reaction parameters were evaluated in the reaction with phenylacetylene $\mathbf{3 a}$, such as reaction time (entry 4), the nitrosating agent (isopentyl nitrite, entry 5) and different temperatures (entries 6-8). However, after performing these reactions, no increments in the yield of 4 a was observed. Then, our attention was focused on the evaluation of the nature of the solvent, and it was observed that neither DMSO or PEG-400 were more effective than nitromethane (entries 9 and 10).

Finally, the reduction of the amount of phenylacetylene 3a and tert-butyl nitrite was evaluated (entries 11 and 12). When the phenylacetylene quantity was reduced to 2 equiv $(0.5 \mathrm{mmol}), 2$-phenylselenopheno[2,3- 
b]pyridine 4a was obtained in comparable yield (entry 3 vs 11). However, the reduction of the nitrite amount from 2.0 equiv to 1.0 equiv $(0.25 \mathrm{mmol})$ resulted in an incomplete consumption of $\mathbf{2 a}$.

Thus, the optimized reaction condition was stablished as stirring a mixture of bis(3-amino-2-pyridyl) diselenide 2a $(0.125 \mathrm{mmol})$, phenylacetylene $3 a(0.5 \mathrm{mmol})$ and tert-butyl nitrite $(0.5 \mathrm{mmol})$ in $\mathrm{CH}_{3} \mathrm{NO}_{2}(1.0 \mathrm{~mL})$, under argon atmosphere at $80{ }^{\circ} \mathrm{C}$ during $2 \mathrm{~h}$. This reaction afforded 2-phenylselenopheno[2,3-b]pyridine $4 \mathrm{a}$ in $41 \%$ yield and the new 1,6-diazaselenanthrene $5 \mathbf{a}$ in $11 \%$ yield.

Table 1. Optimization of the reaction conditions to prepare 2-phenylselenopheno[2,3-b]pyridine $4 a^{a}$

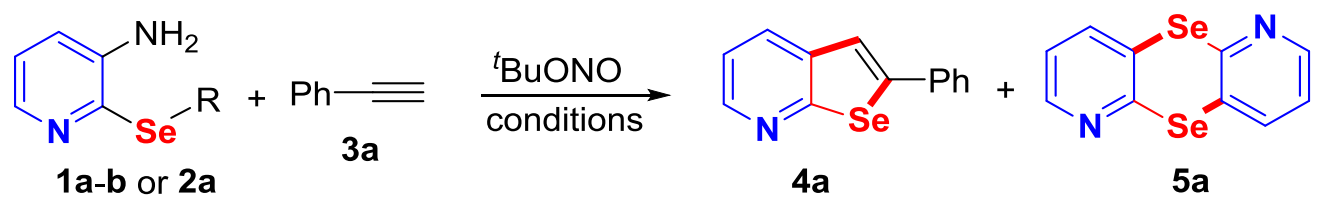

\begin{tabular}{|c|c|c|c|c|c|c|}
\hline Entry & $\mathrm{R}(\mathbf{1}$ or $\mathbf{2})$ & Solvent & Temp. $\left({ }^{\circ} \mathrm{C}\right)$ & $\begin{array}{l}\text { Time } \\
\text { (h) }\end{array}$ & Yield $4 a(\%)^{b}$ & Yield $5 a(\%)^{b}$ \\
\hline $1^{c}$ & $\begin{array}{c}\mathrm{CH}_{3} \\
1 \mathrm{a}\end{array}$ & $\mathrm{CH}_{3} \mathrm{NO}_{2}$ & 80 & 2.0 & 27 & - \\
\hline $2^{c}$ & $\begin{array}{c}\mathrm{C}_{4} \mathrm{H}_{9} \\
\mathbf{1 b}\end{array}$ & $\mathrm{CH}_{3} \mathrm{NO}_{2}$ & 80 & 2.0 & 23 & - \\
\hline 3 & ${ }^{N a}{ }^{S^{-i-}}$ & $\mathrm{CH}_{3} \mathrm{NO}_{2}$ & 80 & 2.0 & 40 & 11 \\
\hline 4 & $2 a$ & $\mathrm{CH}_{3} \mathrm{NO}_{2}$ & 80 & 17.0 & 30 & 13 \\
\hline 5 & $2 a$ & $\mathrm{CH}_{3} \mathrm{NO}_{2}$ & 80 & 2.0 & 20 & 9 \\
\hline 6 & $2 a$ & $\mathrm{CH}_{3} \mathrm{NO}_{2}$ & 25 & 24.0 & 18 & 7 \\
\hline 7 & $2 a$ & $\mathrm{CH}_{3} \mathrm{NO}_{2}$ & 50 & 4.0 & 21 & 7 \\
\hline 8 & $2 a$ & $\mathrm{CH}_{3} \mathrm{NO}_{2}$ & 101 & 2.0 & 33 & 11 \\
\hline 9 & $2 a$ & DMSO & 80 & 2.0 & 15 & 4 \\
\hline 10 & $2 a$ & PEG-400 & 80 & 2.0 & - & - \\
\hline $11^{d}$ & $2 a$ & $\mathrm{CH}_{3} \mathrm{NO}_{2}$ & 80 & 2.0 & 41 & 11 \\
\hline $12^{\mathrm{e}}$ & $2 a$ & $\mathrm{CH}_{3} \mathrm{NO}_{2}$ & 80 & 2.0 & 19 & 8 \\
\hline
\end{tabular}

${ }^{a}$ The mixture of compound $2(0.125 \mathrm{mmol})$, phenylacetylene $3 \mathrm{a}(0.75 \mathrm{mmol})$, and ${ }^{\mathrm{t}} \mathrm{BuONO}(0.5 \mathrm{mmol})$ in the respective solvent $(1.0 \mathrm{~mL})$ was stirred at $80{ }^{\circ} \mathrm{C}$ under $\mathrm{Ar} .{ }^{\mathrm{b}}$ Yield are given for isolated products $4 \mathrm{a}$ and $5 \mathrm{a}$. ${ }^{\mathrm{c}}$ $0.25 \mathrm{mmol}$ of 1 . $^{\mathrm{d}} 0.50 \mathrm{mmol}$ of phenylacetylene 3 a was used. ${ }^{\mathrm{e}} 0.25 \mathrm{mmol}$ of ${ }^{t}$ BuONO was used.

With the optimized conditions in hand, we investigated the substrate scope, performing reactions with different aryl- and alkylacetylenes $\mathbf{3 b}$ - $\mathbf{f}$ and the results are presented in Table 2 . In general, all reactions proceeded smoothly, providing the desired products in moderate yields.

When the reaction was performed with arylacetylenes with electron-donating groups at the para-position of the aromatic ring (3b-d), the obtained results were similar to that obtained using the neutral phenylacetylene 3a (Table 2, entries 2-4 vs entry 1). In contrast, in the presence of the electron-withdrawing $\mathrm{Cl}$-substituent at the aromatic ring $(3 e)$ the reaction was faster, but the yield was not satisfactory $(10 \%)$ and many by-products were observed (Table 2, entry 5). 
The aliphatic heptyne $\mathbf{3 f}$ was also used and the respective 2-pentylselenopheno[2,3-b]pyridine $\mathbf{4 f}$ was obtained after $2 \mathrm{~h}$ in $17 \%$ yield. In all cases 1,6-diazaselenanthrene $\mathbf{5 a}$ was formed and isolated, as depicted in Table 2. Interestingly, for all the conducted reactions the yield of 5 a was similar, ranging from $7 \%$ to $13 \%$.

Table 2. Synthesis of 2-aryl- and 2-alkylselenopheno[2,3-b]pyridines $4 a-f^{a}$

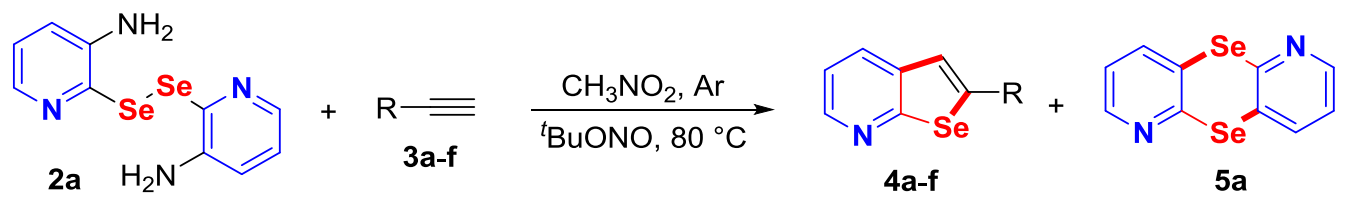

Entry Rend. 4 (\%) ${ }^{\mathrm{b}}$ Rend. 5a (\%)

${ }^{\mathrm{a}}$ The mixture of compound $2 \mathrm{a}(0.125 \mathrm{mmol})$, acetylene $3(0.5 \mathrm{mmol})$, and ${ }^{t} \mathrm{BuONO}(0.5 \mathrm{mmol})$ was added in $\mathrm{CH}_{3} \mathrm{NO}_{2}(1.0 \mathrm{~mL})$ under argon atmosphere and stirred for the indicated time at $80{ }^{\circ} \mathrm{C} .{ }^{\mathrm{b}}$ Yields are given for isolated products $\mathbf{4 a - f}$ and $\mathbf{5 a}$.

To confirm the chemical structure of 1,6-diazaselenanthrene $\mathbf{5 a}$, in addition to NMR collected data, the compound was recrystallized and analyzed by single-crystal X-ray diffraction analysis. The molecular structure obtained is demonstrated in Figure 2. 


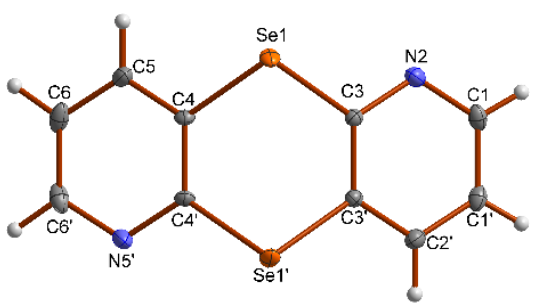

Figure 2. Molecular structure of compound 5a with ellipsoids at the $50 \%$ probability level. Symmetry operation used: (') =x, 0.5-y, z.

Once the structure of 1,6-diazaselenanthrene 5a was confirmed, we turn to carried out reactions in absence of acetylene 3, under the same conditions, to allow the selective formation of product 5a. When bis(3-amino-2pyridyl) diselenide $2 \mathrm{a}$ was allowed to react with tert-butyl nitrite in nitromethane at $80{ }^{\circ} \mathrm{C}, 1,6$ diazaselenanthrene $\mathbf{5 a}$ was obtained in $47 \%$ yield after $2 \mathrm{~h}$ (Table 3, entry 1). After this test, different amounts of the nitrosating agent were evaluated, but lower yields were observed.

Subsequently, the performance of bis(3-amino-2-pyridyl) diselenide $\mathbf{2} \mathbf{b}$, containing a methyl group at the aromatic pyridine ring and the chloro-substituted compound $\mathbf{2 c}$, was evaluated. In these reactions, the expected products $5 \mathbf{b}$ and $\mathbf{5 c}$ were obtained in $41 \%$ and $43 \%$ yields, respectively (Table 3 , entries 2 and 3 ).

Table 3. Synthesis of 1,6-diazaselenanthrenes $5 a-c^{a}$

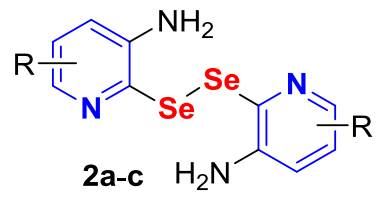

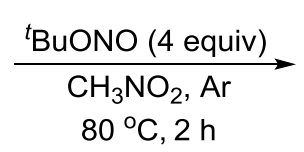

$80^{\circ} \mathrm{C}, 2 \mathrm{~h}$

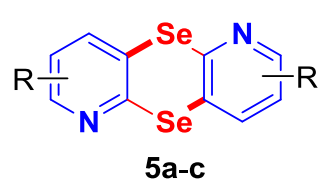

5a-c

Entry Rend. (\%)

${ }^{a}$ The mixture of compound $2 \mathrm{a}-\mathrm{c}(0.125 \mathrm{mmol})$ and ${ }^{t} \mathrm{C}_{4} \mathrm{H}_{9} \mathrm{ONO}(0.5 \mathrm{mmol})$ was added in $\mathrm{CH}_{3} \mathrm{NO}_{2}(1.0 \mathrm{~mL})$ under argon atmosphere and stirred for 2 hours at $80{ }^{\circ} \mathrm{C} .{ }^{\mathrm{b}}$ The yield is given for isolated products 5 a-c. 


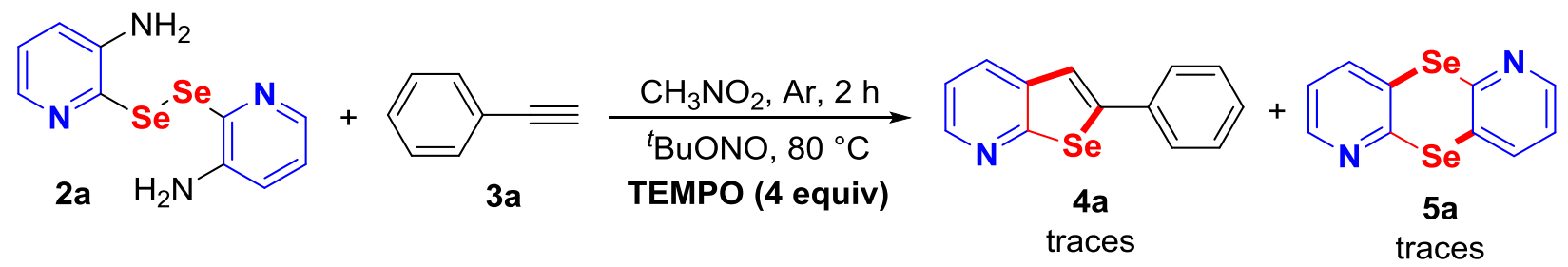

Scheme 3. Control experiment.

Aiming to collect evidences into the reaction pathway, a control experiment was conducted. Thus, the radical trapping experiment was conducted in the presence of the radical inhibitor 2,2,6,6-tetramethyl-1piperidinyloxy (TEMPO) under the standard conditions. Under this condition, a complex mixture was obtained and only traces of compounds $\mathbf{4 a}$ and $\mathbf{5} \mathbf{a}$ were detected by GC/MS analysis. Through this experiment, and based in our findings and previous reports, ${ }^{8,36}$ a plausible mechanism is proposed in Scheme 4. Firstly, the reaction between pyridylamine and tert-butyl nitrite results in radical species $\mathbf{A}$. From this intermediate $\mathbf{A}$ the reaction can follow two paths, depending on the interaction or not with acetylene. In Path I, the reaction occurs without the presence of acetylene $\mathbf{3}$ via two intramolecular radical reactions to afford the product $\mathbf{5}$. In Path II, however, occurs the reaction between the radical intermediate $\mathbf{A}$ and the acetylene $\mathbf{3}$, affording the vinyl radical $\mathbf{B}$, which reacts via intramolecular homolytic substitution at the selenium atom, leading to the final product 4.

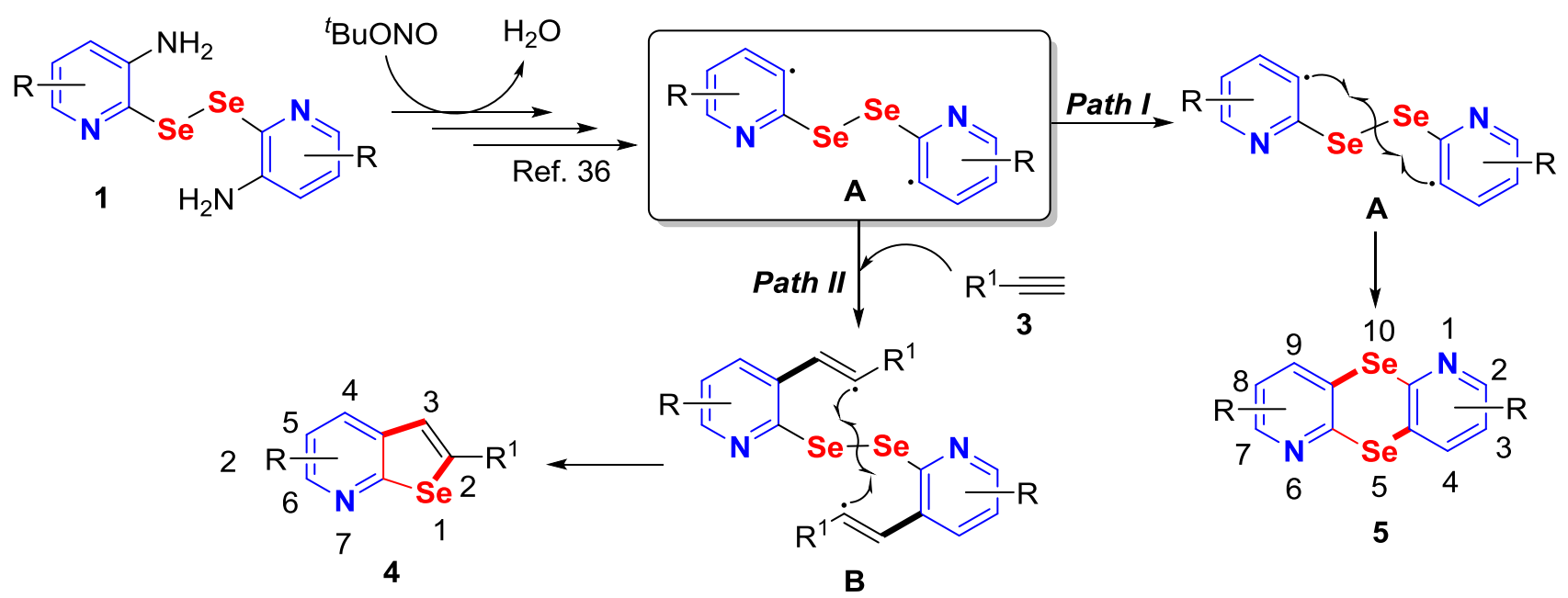

Scheme 4. Proposed mechanism.

To demonstrate the synthetic applicability of the prepared 2-phenylselenopheno[2,3-b]pyridines, compound 4a was reacted with molecular bromine, using dry chloroform as solvent at $0{ }^{\circ} \mathrm{C}$, affording, after $1 \mathrm{~h}, 3$-bromo2-phenylselenopheno[2,3-b]pyridine 6 in $92 \%$ yield (Scheme $5-A) .{ }^{37}$ This is a valuable finding because 3haloselenophenes are versatile substrates for several classic cross-coupling reactions, such as Suzuki-Miyaura, Sonogashira and Negishi, among others. ${ }^{17,38}$ In another reaction, compound 4a was reacted with diphenyl diselenide in the presence of $\mathrm{Oxone}^{\circledast}$ in $\mathrm{AcOH}$ at $100{ }^{\circ} \mathrm{C}$. The electrophilic selenium species generated in situ reacted with $4 \mathrm{a}$ to give 2-phenyl-3-(phenylselanyl)selenopheno[2,3-b]pyridine 7 in $85 \%$ yield after $12 \mathrm{~h}$ (Scheme 5-B). ${ }^{39}$ 


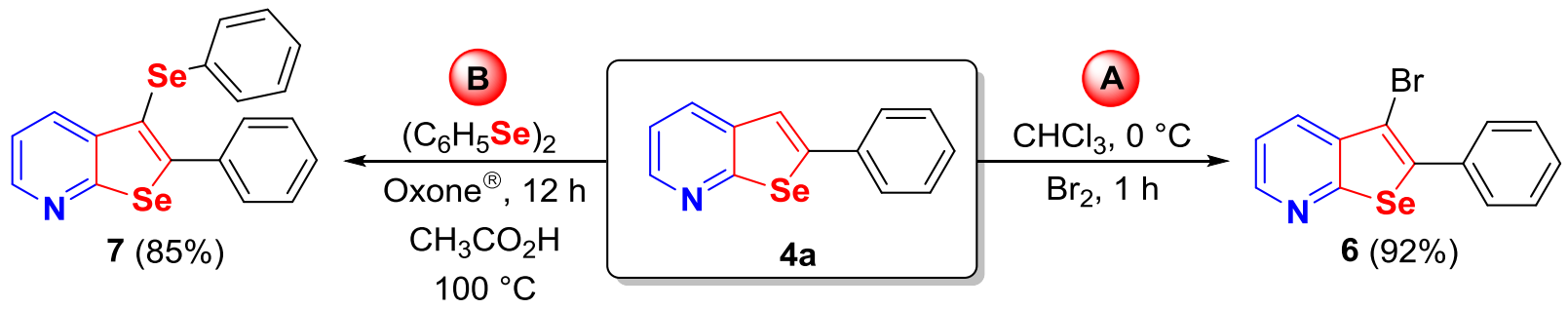

Scheme 5. Synthetic applications for compound 4a.

\section{Conclusions}

In summary, we have developed a simple method for the synthesis of 2-organylselenopheno[2,3-b]pyridines in short reaction times and mild conditions. To allow these synthesis bis(3-amino-2-pyridyl) diselenide was reacted with terminal alkynes in the presence of tert-butyl nitrite as nitrosating agent. Also, it was possible to obtain a new class of 1,6-diazaselenanthrenes, which were obtained in good yields when the reaction was conducted without the presence of alkynes. In addition, the applicability of selenopheno[2,3-b]pyridines was demonstrated by bromination and direct selanylation reactions to obtain versatile substrates for further organic transformations capable to produce promising drugs or precursors for new materials.

\section{Experimental Section}

General. The reactions were monitored by TLC carried out on Merk silica gel (60 F254) by using UV light as visualization agent and the mixture between $5 \%$ of vanillin in $10 \%$ of $\mathrm{H}_{2} \mathrm{SO}_{4}$ under heating conditions as developing agents. Merck silica gel (particle size 0.040-0.063 mm) was used to flash chromatography. Hydrogen nuclear magnetic resonance spectra $\left({ }^{1} \mathrm{H}\right.$ NMR) were obtained on Bruker Avance III HD $400 \mathrm{MHz}$ employing a direct broadband probe at $400 \mathrm{MHz}$. The spectra were recorded in $\mathrm{CDCl}_{3}$ solutions. The chemical shifts are reported in ppm, referenced to tetramethylsilane (TMS) as the internal reference. Coupling constants $(J)$ are reported in Hertz. Abbreviations to denote the multiplicity of a particular signal are brs (broad singlet) s (singlet), d (doublet), dd (doublet of doublets), t (triplet), q (quartet), quint (quintet) and $\mathrm{m}$ (multiplet). Carbon-13 nuclear magnetic resonance spectra $\left({ }^{13} \mathrm{C} \mathrm{NMR}\right)$ were obtained on Bruker Avance III HD $400 \mathrm{MHz}$ employing a direct broadband probe at $100 \mathrm{MHz}$. The chemical shifts are reported in ppm, referenced to the solvent peak of $\mathrm{CDCl}_{3}$. Selenium-77 nuclear magnetic resonance spectra ( ${ }^{77}$ Se NMR) were obtained on Bruker Avance III HD $400 \mathrm{MHz}$ employing a direct broadband probe at $76 \mathrm{MHz}$. The chemical shifts are reported in ppm using as solvent the $\mathrm{CDCl}_{3}$ and as an internal standard the diphenyl diselenide. The high-resolution electrospray ionization mass spectrometry (ESI-QTOF) analysis were performed on a Bruker Daltonics microTOF-Q II instrument in positive mode. The samples were solubilized in HPLC-grade acetonitrile and injected into the APCl source by means of a syringe pump at a flow rate of $5.0 \mu \mathrm{L} \mathrm{min}{ }^{-1}$. The follow instrument parameters were applied: capillary and cone voltages were set to $+3500 \mathrm{~V}$ and $-500 \mathrm{~V}$, respectively, with a desolvation temperature of $180{ }^{\circ} \mathrm{C}$. For data acquisition and processing, Compass 1.3 for microTOF-Q II software (Bruker daltonics, USA) was used. The data were collected in the $\mathrm{m} / \mathrm{z}$ range of 50-1200 at the speed of two scans per second. Low-resolution mass spectra were obtained with a Shimadzu GC-MS-QP2010P mass spectrometer. Melting point (mp) 
values were measured in a Marte PFD III instrument with a $0.1^{\circ} \mathrm{C}$ precision.

General procedure for synthesis of 2-aryl- or 2-alkylselenopheno[2,3-b]pyridines 4a-f. In a Schlenk tube was prepared a mixture of bis(3-amino-2-pyridyl) diselenide $2 \mathbf{2 a}(0.125 \mathrm{mmol})$, alkyne $3 a-f(0.5 \mathrm{mmol})$, and ${ }^{t} \mathrm{C}_{4} \mathrm{H}_{9} \mathrm{ONO}(0.5 \mathrm{mmol})$ in $\mathrm{CH}_{3} \mathrm{NO}_{2}(1.0 \mathrm{~mL})$ under argon atmosphere. This reaction mixture was stirred at 80 ${ }^{\circ} \mathrm{C}$ for the time indicated in Table 2 . Then, water was added $(25.0 \mathrm{~mL})$ and the reaction was extracted with ethyl acetate (3x $10.0 \mathrm{~mL}$ ). The organic phase was separated, dried over $\mathrm{MgSO}_{4}$, and the solvent was evaporated under reduced pressure. The product was isolated by column chromatography using hexane/ethyl acetate as eluent.

2-Phenylselenopheno[2,3-b]pyridine (4a). Following general procedure, the residue was purified by column chromatography on silica gel, $\left(R_{f}=0.6\right.$ in hexane/EtOAc $\left.=9: 1\right)$, to furnish $4 a$ as a slightly yellowish solid (0.027 $\mathrm{g}, 41 \%$ yield), $\mathrm{mp} 86-88{ }^{\circ} \mathrm{C} .{ }^{1} \mathrm{H}$ NMR $\left(\mathrm{CDCl}_{3}, 400 \mathrm{MHz}\right) \delta(\mathrm{ppm})=8.45$ (dd, J 4.7 and $\left.1.7 \mathrm{~Hz}, 1 \mathrm{H}, \mathrm{H}-6\right), 7.94(\mathrm{dd}, J$ 8.0 and $1.7 \mathrm{~Hz}, 1 \mathrm{H}, \mathrm{H}-4)$, 7.65-7.62 (m, 2H, ArH), $7.56(\mathrm{~s}, 1 \mathrm{H}, \mathrm{H}-3), 7.44-7.33(\mathrm{~m}, 3 \mathrm{H}, \mathrm{ArH}), 7.27(\mathrm{dd}, J 8.0$ and $4.7 \mathrm{~Hz}, 1 \mathrm{H}, \mathrm{H}-5) .{ }^{13} \mathrm{C} \mathrm{NMR}\left(\mathrm{CDCl}_{3}, 100 \mathrm{MHz}\right) \delta(\mathrm{ppm})=164.6$ (C), 148.8 (C), $145.9(\mathrm{CH}), 137.6$ (C), 135.7 (C), $131.9(\mathrm{CH}), 129.0(2 \times \mathrm{CH}), 128.7(\mathrm{CH}), 126.9$ (2 x CH), $120.0(\mathrm{CH}), 119.8(\mathrm{CH}) . \mathrm{MS}$ (rel. int., \%) m/z: $259(100.0)$, 179 (26.4), 129 (10.6), 115 (4.0), 102 (5.0). HRMS (APCI-QTOF) calculated mass for $\mathrm{C}_{13} \mathrm{H}_{9} \mathrm{NSe}[\mathrm{M}+\mathrm{H}]^{+}:$259.9978, found: 259.9984 .

2-(4-Tolyl)selenopheno[2,3-b]pyridine (4b). Following general procedure, the residue was purified by column chromatography on silica gel, $\left(R_{f}=0.6\right.$ in hexane/EtOAc $\left.=9: 1\right)$, to furnish $\mathbf{4 b}$ as a yellow solid $(0.024 \mathrm{~g}, 35 \%$ yield), mp 108-109 ${ }^{\circ} \mathrm{C} .{ }^{1} \mathrm{H} \mathrm{NMR}\left(\mathrm{CDCl}_{3}, 400 \mathrm{MHz}\right) \delta(\mathrm{ppm})=8.43$ (dd, J 4.6 and $\left.1.6 \mathrm{~Hz}, 1 \mathrm{H}, \mathrm{H}-6\right), 7.93$ (dd, J 7.9 and $1.6 \mathrm{~Hz}, 1 \mathrm{H}, \mathrm{H}-4), 7.55-7.52(\mathrm{~m}, 3 \mathrm{H}, \mathrm{H}-3$ and $\mathrm{ArH}), 7.26(\mathrm{dd}, J 7.9$ and $4.6 \mathrm{~Hz}, 1 \mathrm{H}, \mathrm{H}-5), 7.22(\mathrm{~d}, J 7.9 \mathrm{~Hz}, 2 \mathrm{H}$, $\mathrm{ArH}) ; 2.39\left(\mathrm{~s}, 3 \mathrm{H}, \mathrm{ArCH}_{3}\right) .{ }^{13} \mathrm{C} \mathrm{NMR}\left(\mathrm{CDCl}_{3}, 100 \mathrm{MHz}\right) \delta(\mathrm{ppm})=164.7$ (C), 149.1 (C), $145.8(\mathrm{CH}), 138.9$ (C), 137.8 (C), $133.1(\mathrm{C}), 131.7(\mathrm{CH}), 129.7(2 \times \mathrm{CH}), 126.8(2 \times \mathrm{CH}), 120.0(\mathrm{CH}), 119.2(\mathrm{CH}), 21.2\left(\mathrm{CH}_{3}\right)$. MS (rel. int., \%) m/z: 273 (100.0), 258 (3.5), 192 (23.7), 115 (8.3), 102 (2.2). HRMS (APCI-QTOF) calculated mass for $\mathrm{C}_{14} \mathrm{H}_{11} \mathrm{NSe}$ $[\mathrm{M}+\mathrm{H}]^{+}: 274.0135$, found: 274.0134 .

2-(4-Ethylphenyl)selenopheno[2,3-b]pyridine (4c). Following general procedure, the residue was purified by column chromatography on silica gel, $\left(R_{f}=0.6\right.$ in hexane/EtOAc $\left.=9: 1\right)$, to furnish $4 \mathrm{c}$ as a slightly yellow solid (0.023 g, 32\% yield), mp 91-93 ${ }^{\circ} \mathrm{C} .{ }^{1} \mathrm{H}$ NMR $\left(\mathrm{CDCl}_{3}, 400 \mathrm{MHz}\right) \delta(\mathrm{ppm})=8.44-8.43(\mathrm{~m}, 1 \mathrm{H}, \mathrm{H}-6), 7.94(\mathrm{dd}, J 7.9$ and $1.3 \mathrm{~Hz}, 1 \mathrm{H}, \mathrm{H}-4), 7.56(\mathrm{~d}, J 8.1 \mathrm{~Hz}, 2 \mathrm{H}, \mathrm{ArH}), 7.53(\mathrm{~s}, 1 \mathrm{H}, \mathrm{H}-3), 7.28-7.24(\mathrm{~m}, 3 \mathrm{H}, \mathrm{H}-5$ and ArH), $2.69(\mathrm{q}, J 7.6$ $\left.\mathrm{Hz}, 2 \mathrm{H}, \mathrm{ArC}_{2} \mathrm{CH}_{3}\right), 1.28\left(\mathrm{t}, J 7.6 \mathrm{~Hz}, 3 \mathrm{H}, \mathrm{ArCH}_{2} \mathrm{CH}_{3}\right) .{ }^{13} \mathrm{C} \mathrm{NMR}\left(\mathrm{CDCl}_{3}, 100 \mathrm{MHz}\right) \delta(\mathrm{ppm})=164.6(\mathrm{C}), 149.1$ (C), $145.7(\mathrm{CH}), 145.3(\mathrm{C}), 137.8$ (C), $133.3(\mathrm{C}), 131.7(\mathrm{CH}), 128.5(2 \times \mathrm{CH}), 126.9(2 \times \mathrm{CH}), 120.0(\mathrm{CH}), 119.2(\mathrm{CH})$, $28.6\left(\mathrm{CH}_{2}\right), 15.4\left(\mathrm{CH}_{3}\right)$. MS (rel. int., \%) m/z: 287 (81.3), 272 (100.0), 191 (15.2), 115 (5.9), 102 (5.0). HRMS (APCl-QTOF) calculated mass for $\mathrm{C}_{15} \mathrm{H}_{13} \mathrm{NSe}[\mathrm{M}+\mathrm{H}]^{+}: 288.0291$, found: 288.0288 .

2-[4-(t-butyl)phenyl]selenopheno[2,3-b]pyridine (4d). Following general procedure, the residue was purified by column chromatography on silica gel, $\left(R_{f}=0.6\right.$ in hexane/EtOAc $\left.=9: 1\right)$, to furnish $4 \mathbf{d}$ as a orange solid $\left(0.024 \mathrm{~g}, 31 \%\right.$ yield), $\mathrm{mp} 95-97{ }^{\circ} \mathrm{C} .{ }^{1} \mathrm{H} \mathrm{NMR}\left(\mathrm{CDCl}_{3}, 400 \mathrm{MHz}\right) \delta(\mathrm{ppm})=8.44(\mathrm{dd}, J 4.7$ and $1.6 \mathrm{~Hz}, 1 \mathrm{H}, \mathrm{H}-6)$, $7.94(\mathrm{dd}, J 7.9$ and $1.6 \mathrm{~Hz}, 1 \mathrm{H}, \mathrm{H}-4), 7.60-7.57(\mathrm{~m}, 2 \mathrm{H}, \mathrm{ArH}), 7.54(\mathrm{~s}, 1 \mathrm{H}, \mathrm{H}-3), 7.46-7.43(\mathrm{~m}, 2 \mathrm{H}, \mathrm{ArH}), 7.27(\mathrm{dd}, J$ 7.9 and $4.7 \mathrm{~Hz}, 1 \mathrm{H}, \mathrm{H}-5), 1.35\left(\mathrm{~s}, 9 \mathrm{H},{ }^{t} \mathrm{C}_{4} \underline{H}_{9}\right) .{ }^{13} \mathrm{C} \mathrm{NMR}\left(\mathrm{CDCl}_{3}, 100 \mathrm{MHz}\right) \delta(\mathrm{ppm})=164.7(\mathrm{C}), 152.1$ (C), $149.0(\mathrm{C})$, $145.8(\mathrm{CH}), 137.8(\mathrm{C}), 133.1(\mathrm{C}), 131.7(\mathrm{CH}), 126.7(2 \times \mathrm{CH}), 126.0(2 \times \mathrm{CH}), 120.0(\mathrm{CH}), 119.3(\mathrm{CH}), 34.7(\mathrm{C}), 31.2$ (3 $\mathrm{x} \mathrm{CH}_{3}$ ). MS (rel. int., \%) m/z: 315 (53.4), 300 (100.0), 284 (4.6), 272 (20.2), 191 (3.5), 115 (5.1), 102 (4.0). HRMS (APCl-QTOF) calculated mass for $\mathrm{C}_{17} \mathrm{H}_{17} \mathrm{NSe}[\mathrm{M}+\mathrm{H}]^{+}: 316.0604$, found: 316.0598 .

2-(4-Chlorophenyl)selenopheno[2,3-b]pyridinepyrazole (4e). Following general procedure, the residue was purified by column chromatography on silica gel, $\left(R_{f}=0.4\right.$ in hexane/EtOAc $\left.=9: 1\right)$, to furnish 4 e as a slightly yellow solid (0.007 g, 10\% yield), mp 91-92 ${ }^{\circ} \mathrm{C} .{ }^{1} \mathrm{H} \mathrm{NMR}\left(\mathrm{CDCl}_{3}, 400 \mathrm{MHz}\right) \delta(\mathrm{ppm})=8.40(\mathrm{dd}, J 4.6$ and $1.0 \mathrm{~Hz}$, 
1H, H-6), $7.91(\mathrm{dd}, J 7.9$ and $1.0 \mathrm{~Hz}, 1 \mathrm{H}, \mathrm{H}-4), 7.51-7.49(\mathrm{~m}, 3 \mathrm{H}, \mathrm{H}-3$ and $\mathrm{ArH}), 7.33(\mathrm{~d}, J$ 8.4, 2H, ArH), $7.23(\mathrm{dd}, J$ 7.9 and $4.6 \mathrm{~Hz}, 1 \mathrm{H}, \mathrm{H}-5) .{ }^{13} \mathrm{C} \mathrm{NMR}\left(\mathrm{CDCl}_{3}, 100 \mathrm{MHz}\right) \delta(\mathrm{ppm})=164.8(\mathrm{C}), 147.4(\mathrm{C}), 146.2(\mathrm{CH}), 137.5$ (C), 134.7 (C), 134.4 (C), $132.1(\mathrm{CH}), 129.2(2 \times \mathrm{CH}), 128.1(2 \times \mathrm{CH}), 120.4(\mathrm{CH}), 120.2(\mathrm{CH}) . \mathrm{MS}$ (rel. int., \%) m/z: 293 (100.0), 258 (13.2), 177 (25.2), 115 (7.5), 102 (2.2). HRMS (APCI-QTOF) calculated mass for $\mathrm{C}_{13} \mathrm{H}_{8} \mathrm{CINSe}[\mathrm{M}+\mathrm{H}]^{+}$: 293.9589, found: 293.9579 .

2-Pentylselenopheno[2,3-b]pyridine (4f). Following general procedure, the residue was purified by column chromatography on silica gel, $\left(R_{f}=0.6\right.$ in hexane/EtOAc $\left.=9: 1\right)$, to furnish $\mathbf{4 f}$ as a orange oil $(0.011 \mathrm{~g}, 17 \%$ yield). ${ }^{1} \mathrm{H} \mathrm{NMR}\left(\mathrm{CDCl}_{3}, 400 \mathrm{MHz}\right) \delta(\mathrm{ppm})=8.39(\mathrm{dd}, J 4.7$ and $1.4 \mathrm{~Hz}, 1 \mathrm{H}, \mathrm{H}-6), 7.84(\mathrm{dd}, J 7.9$ and $1.4 \mathrm{~Hz}, 1 \mathrm{H}$, $\mathrm{H}-4$ ), 7.23 (dd, J 7.9 and $4.7 \mathrm{~Hz}, 1 \mathrm{H}, \mathrm{H}-5$ ), $7.05(\mathrm{~s}, 1 \mathrm{H}, \mathrm{H}-3), 2.95\left(\mathrm{t}, J 7.4 \mathrm{~Hz}, 2 \mathrm{H}, \mathrm{CH}_{2}\right.$ ), 1.75 (quint, $J .4 \mathrm{~Hz}, 2 \mathrm{H}$, $\left.\mathrm{CH}_{2}\right), 1.41-1.34\left(\mathrm{~m}, 4 \mathrm{H}, 2 \times \mathrm{CH}_{2}\right), 0.91\left(\mathrm{t}, J 7.4 \mathrm{~Hz}, 3 \mathrm{H}, \mathrm{CH}_{3}\right) \cdot{ }^{13} \mathrm{C} \mathrm{NMR}\left(\mathrm{CDCl}_{3}, 100 \mathrm{MHz}\right) \delta(\mathrm{ppm})=164.8(\mathrm{C})$, $152.9(\mathrm{C}), 145.1(\mathrm{CH}), 136.9(\mathrm{C}), 130.9(\mathrm{CH}), 120.9(\mathrm{CH}), 119.6(\mathrm{CH}), 33.8\left(\mathrm{CH}_{2}\right), 31.3\left(\mathrm{CH}_{2}\right), 31.2\left(\mathrm{CH}_{2}\right), 22.4$ $\left(\mathrm{CH}_{2}\right), 13.9\left(\mathrm{CH}_{3}\right)$. MS (rel. int., \%) m/z: 253 (50.4), 196 (100.0), 116 (52.5), 104 (14.1), 77 (7.6). HRMS (APClQTOF) calculated mass for $\mathrm{C}_{12} \mathrm{H}_{15} \mathrm{NSe}[\mathrm{M}+\mathrm{H}]^{+}: 254.0448$, found: 254.0448 .

General procedure for synthesis of 1,6-diazaselenanthrenes 5a-c. In a Schlenk tube was added bis(3amino-2-pyridyl) diselenide $2 \mathrm{a}(0.125 \mathrm{mmol})$ and ${ }^{t} \mathrm{C}_{4} \mathrm{H}_{9} \mathrm{ONO}(0.5 \mathrm{mmol})$ in $\mathrm{CH}_{3} \mathrm{NO}_{2}(1.0 \mathrm{~mL})$ under argon atmosphere. Then, the reaction mixture was stirred at $80^{\circ} \mathrm{C}$ for the time indicated in Table 3 . After that, water was added $(25.0 \mathrm{~mL})$ and the reaction mixture extracted with ethyl acetate $(3 \times 10.0 \mathrm{~mL})$. The organic phase was separated, dried over $\mathrm{MgSO}_{4}$, and the solvent was evaporated under reduced pressure. The product was isolated by column chromatography using hexane/ethyl acetate as eluent.

1,6-Diazaselenanthrene (5a). Following general procedure, the residue was purified by column chromatography on silica gel, $\left(R_{f}=0.1\right.$ in hexane/EtOAc $\left.=9: 1\right)$, to furnish 5 a as a slightly yellow solid (0.018 g, 47\% yield), mp $180-182{ }^{\circ} \mathrm{C} .{ }^{1} \mathrm{H} \mathrm{NMR}\left(\mathrm{CDCl}_{3}, 400 \mathrm{MHz}\right) \delta(\mathrm{ppm})=8.43(\mathrm{dd}, J 4.7$ and $1.7 \mathrm{~Hz}, 2 \mathrm{H}, \mathrm{H}-$ 2 and $\mathrm{H}-7$ ), 7.88 (dd, $J 7.8$ and $1.7 \mathrm{~Hz}, 2 \mathrm{H}, \mathrm{H}-4$ and $\mathrm{H}-9$ ), 7.17 (dd, J 7.8 and $4.7 \mathrm{~Hz}, 2 \mathrm{H}, \mathrm{H}-3 \mathrm{and} \mathrm{H-8).}{ }^{13} \mathrm{C}$ $\mathrm{NMR}\left(\mathrm{CDCl}_{3}, 100 \mathrm{MHz}\right) \delta(\mathrm{ppm})=155.9(2 \times \mathrm{C}), 148.5(2 \times \mathrm{CH}), 138.5(2 \times \mathrm{CH}), 130.0(2 \times \mathrm{C}), 122.8(2 \times \mathrm{CH})$. MS (rel. int., \%) m/z: 314 (51.4), 234 (100.0), 154 (10.8), 127 (19.5), 117 (5.7). HRMS (APCI-QTOF) calculated mass for $\mathrm{C}_{10} \mathrm{H}_{6} \mathrm{~N}_{2} \mathrm{Se}_{2}[\mathrm{M}+\mathrm{H}]^{+}$: 314.8940, found: 314.8939. Crystal data: Orthorhombic, space group Pnma, $\mathrm{T}=100(2) \mathrm{K}, \mathrm{a}=20.9745(11) \AA, \mathrm{b}=11.4151(6) \AA, c=3.9409(2) \AA, \alpha=90^{\circ}, \beta=90^{\circ}, \gamma=90^{\circ}, \mathrm{V}$ $=943.55(8) \AA^{3}, Z=4$, Bruker APEX-II CCD, Mo K $\alpha$ radiation $\left(\lambda=0.71073 \AA\right.$ ),$\mu=7.791 \mathrm{~mm}^{-1}$, absorption correction: multi-scan, $\operatorname{Tmin}=0.5234, \mathrm{Tmax}=0.7461$. Structure solution and refinement: SHELXL-2014, [G. M. Sheldrick, SHELXS-2014, Program for Crystal Structure Solution, University of Göttingen, 2014]. R1 = $0.0481, \mathrm{wR} 2=0.0847, \mathrm{GooF}=1.401$. The crystallographic data (CCDC 1911570) have been deposited in the Cambridge Crystallographic Data Centre.

4,9-Dimethyl-1,6-diazaselenanthrene (5b). Following general procedure, the residue was purified by column chromatography on silica gel, $\left(R_{f}=0.3\right.$ in hexane/EtOAc $\left.=9: 1\right)$, to furnish $5 \mathbf{b}$ as a white solid $(0.018 \mathrm{~g}, 41 \%$ yield), mp $220-222{ }^{\circ} \mathrm{C}^{1}{ }^{\mathrm{H}} \mathrm{NMR}\left(\mathrm{CDCl}_{3}, 400 \mathrm{MHz}\right) \delta(\mathrm{ppm})=8.22(\mathrm{~d}, \mathrm{~J} 4.8 \mathrm{~Hz}, 2 \mathrm{H}, \mathrm{H}-2$ and H-7), 7.01 (d, J $4.8 \mathrm{~Hz}$, $2 \mathrm{H}, \mathrm{H}-3$ and $\mathrm{H}-8), 2.44\left(\mathrm{~s}, 6 \mathrm{H}, \mathrm{CH}_{3}-4\right.$ and $\left.\mathrm{CH}_{3}-9\right) .{ }^{13} \mathrm{C} \mathrm{NMR}\left(\mathrm{CDCl}_{3}, 100 \mathrm{MHz}\right) \delta(\mathrm{ppm})=155.3(2 \times \mathrm{C}), 148.3(2 \mathrm{x}$ C), $148.1(2 \times \mathrm{CH}), 132.1(2 \times \mathrm{C}), 124.1(2 \times \mathrm{CH}), 22.9\left(2 \times \mathrm{CH}_{3}\right) . \mathrm{MS}$ (rel. int., \%) m/z: 342 (53.2), 262 (100.0), 247 (6.9), 234 (6.4), 154 (10.0), 127 (6.1) 117 (6.7). HRMS (APCI-QTOF) calculated mass for $\mathrm{C}_{12} \mathrm{H}_{10} \mathrm{~N}_{2} \mathrm{Se}_{2}[\mathrm{M}+\mathrm{H}]^{+}$: 342.9253, found: 342.9258 .

3,8-Dichloro-1,6-diazaselenanthrene (5c). Following general procedure, the residue was purified by column chromatography on silica gel, $\left(R_{f}=0.7\right.$ in hexane/EtOAc $\left.=9: 1\right)$, to furnish $5 c$ as a white solid $(0.021 \mathrm{~g}, 43 \%$ yield), mp $170-171^{\circ} \mathrm{C} .{ }^{1} \mathrm{H} \mathrm{NMR}\left(\mathrm{CDCl}_{3}, 400 \mathrm{MHz}\right) \delta(\mathrm{ppm})=8.32(\mathrm{~d}, \mathrm{~J} 2.3 \mathrm{~Hz}, 2 \mathrm{H}, \mathrm{H}-2$ and H-7), 7.80 (d, J $2.3 \mathrm{~Hz}$, $2 \mathrm{H}, \mathrm{H}-4$ and $\mathrm{H}-9) .{ }^{13} \mathrm{C} \mathrm{NMR}\left(\mathrm{CDCl}_{3}, 100 \mathrm{MHz}\right) \delta(\mathrm{ppm})=153.1(2 \times \mathrm{C}), 147.4(2 \times \mathrm{CH}), 137.9(2 \times \mathrm{CH}), 131.8(2 \times$ 
C), 131.0 (2 x C). MS (rel. int., \%) m/z: 382 (60.9), 302 (100.0), 267 (27.9), 231 (6.3), 154 (5.8). HRMS (APClQTOF) calculated mass for $\mathrm{C}_{10} \mathrm{H}_{4} \mathrm{Cl}_{2} \mathrm{~N}_{2} \mathrm{Se}_{2}[\mathrm{M}+\mathrm{H}]^{+}: 382.8160$, found: 382.8140 .

General procedure for synthesis of 3-bromo-2-phenylselenopheno[2,3-b]pypidine 6. In a reaction flask of $25.0 \mathrm{~mL}$ was added 2-phenylselenopheno[2,3-b]pyridine $4 \mathrm{a}(0.25 \mathrm{mmol})$ in $\mathrm{CHCl}_{3}(4.0 \mathrm{~mL})$ and the mixture was cooled to $0{ }^{\circ} \mathrm{C}$. Then a solution of $\mathrm{Br}_{2}(0.37 \mathrm{mmol})$ in $\mathrm{CHCl}_{3}(1 \mathrm{~mL})$ was added dropwise. The reaction mixture was stirred at $0{ }^{\circ} \mathrm{C}$ for $1.0 \mathrm{~h}$ resulting in a yellowish solution. Then, an aqueous saturated solution of $\mathrm{Na}_{2} \mathrm{~S}_{2} \mathrm{O}_{3}$ $(25.0 \mathrm{~mL})$ and ethyl acetate $(15.0 \mathrm{~mL})$ were added. The organic phase was washed with water $(2 \times 10.0 \mathrm{~mL})$, separated, dried over $\mathrm{MgSO}_{4}$, and the solvent was removed under reduced pressure. The product was isolated by column chromatography using hexane/ethyl acetate as eluent.

3-Bromo-2-phenylselenopheno[2,3-b]pyridine (6). Following general procedure, the residue was purified by column chromatography on silica gel, $\left(R_{f}=0.5\right.$ in hexane/EtOAc $\left.=9: 1\right)$, to furnish 6 as a orange solid $(0.077 \mathrm{~g}$, 92\% yield), mp 47-48 ${ }^{\circ} \mathrm{C} .{ }^{1} \mathrm{H} \mathrm{NMR}\left(\mathrm{CDCl}_{3}, 400 \mathrm{MHz}\right) \delta(\mathrm{ppm})=7.61$ (dd, J 4.6 and $\left.1.5 \mathrm{~Hz}, 1 \mathrm{H}, \mathrm{H}-6\right), 7.19-7.16$ (m, $1 \mathrm{H}, \mathrm{H}-4), 7.78-6.75(\mathrm{~m}, 2 \mathrm{H}, \mathrm{ArH}), 6.57-6.47(\mathrm{~m}, 4 \mathrm{H}, \mathrm{ArH}$ and $\mathrm{H}-5) .{ }^{13} \mathrm{C} \mathrm{NMR}\left(\mathrm{CDCl}_{3}, 100 \mathrm{MHz}\right) \delta(\mathrm{ppm})=162.2$ (C), $147.2(\mathrm{CH}), 142.3$ (C), 136.0 (C), 134.4 (C), $133.0(\mathrm{CH}), 129.8(2 \times \mathrm{CH}), 129.0(\mathrm{CH}), 128.6(2 \times \mathrm{CH}), 120.7(\mathrm{CH})$, 103.7 (C). MS (rel. int., \%) m/z: 337 (100.0), 258 (32.8), 178 (32.8), 129 (15.8), 115 (7.0). HRMS (APCI-QTOF) calculated mass for $\mathrm{C}_{13} \mathrm{H}_{8} \mathrm{BrNSe}[\mathrm{M}+\mathrm{H}]^{+}: 337.9084$, found: 337.9084 .

General procedure for synthesis of 2-phenyl-3-(phenylselanyl)selenopheno[2,3-b]pyridine 7. In a reaction tube of $10.0 \mathrm{~mL}$ was added 2-phenylselenopheno[2,3-b]pypidine $\mathbf{4 a}$ (0,1 mmol), diphenyl diselenide $(0.1$ $\mathrm{mmol}$ ) and Oxone ${ }^{\circledR}(0.2 \mathrm{mmol})$ in $\mathrm{AcOH}(1.0 \mathrm{~mL})$. The mixture was stirred at $100{ }^{\circ} \mathrm{C}$ for $12 \mathrm{~h}$. After, a $5 \%$ aqueous $\mathrm{NaHCO}_{3}$ solution $(10.0 \mathrm{~mL})$ and ethyl acetate $(15.0 \mathrm{~mL})$ were added. The organic phase was washed with water (3x $10.0 \mathrm{~mL}$ ), separated, dried over $\mathrm{MgSO}_{4}$, and the solvent was evaporated under reduced pressure. The product was isolated by column chromatography using hexane/ethyl acetate as eluent.

2-Phenyl-3-(phenylselanyl)selenopheno[2,3-b]pyridine (7). Following general procedure, the residue was purified by column chromatography on silica gel, $\left(R_{f}=0.5\right.$ in hexane/EtOAc $\left.=9: 1\right)$, to furnish 7 as a yellowish solid $\left(0.035 \mathrm{~g}, 85 \%\right.$ yield), mp $112-113^{\circ} \mathrm{C} .{ }^{1} \mathrm{H} \mathrm{NMR}\left(\mathrm{CDCl}_{3}, 400 \mathrm{MHz}\right) \delta(\mathrm{ppm})=8.50(\mathrm{dd}, \mathrm{J} 4.6$ and $1.6 \mathrm{~Hz}, 1 \mathrm{H}, \mathrm{H}-$ 6), $8.08(\mathrm{dd}, J 8.0$ and $1.6 \mathrm{~Hz}, 1 \mathrm{H}, \mathrm{H}-4), 7.59-7.57(\mathrm{~m}, 2 \mathrm{H}, \mathrm{ArH}), 7.43-7.38(\mathrm{~m}, 3 \mathrm{H}, \mathrm{ArH}), 7.28(\mathrm{dd}, J 8.0$ and 4.6 $\mathrm{Hz}, 1 \mathrm{H}, \mathrm{H}-5), 7.14-7.11(\mathrm{~m}, 5 \mathrm{H}, \mathrm{ArH}) .{ }^{13} \mathrm{C} \mathrm{NMR}\left(\mathrm{CDCl}_{3}, 100 \mathrm{MHz}\right) \delta(\mathrm{ppm})=164.5(\mathrm{C}), 154.1(\mathrm{C}), 146.9(\mathrm{CH})$, $138.6(\mathrm{C}), 135.7$ (C), $134.4(\mathrm{CH}), 132.3$ (C), $130.0(2 \times \mathrm{CH}), 129.3(2 \times \mathrm{CH}), 129.0(2 \times \mathrm{CH}), 128.97(\mathrm{CH}), 128.3(2 \times$ $\mathrm{CH}), 126.2(\mathrm{CH}), 120.6(\mathrm{CH}), 115.8(\mathrm{C}) .{ }^{77} \mathrm{Se} \mathrm{NMR}\left(\mathrm{CDCl}_{3}, 76 \mathrm{MHz}\right) \delta(\mathrm{ppm})=606.1,277.9 . \mathrm{MS}$ (rel. int., \%) $\mathrm{m} / \mathrm{z}$ : 415 (73.2), 335 (100.0), 254 (76.4), 177 (35.7), 151 (40.0), 77 (30.2). HRMS (APCI-QTOF) calculated mass for $\mathrm{C}_{19} \mathrm{H}_{13} \mathrm{NSe}_{2}[\mathrm{M}+\mathrm{H}]^{+}:$415.9457, found: 415.9464 .

\section{Acknowledgements}

The authors thank the Fundação de Amparo à Pesquisa do Estado do Rio Grande do Sul (FAPERGS) (ARD 16/2551-0000358-0 and PqG 17/25510000964-9), Conselho Nacional de Desenvolvimento Científico e Tecnológico (CNPq) and Financiadora de Inovação e Pesquisa (FINEP) for the financial support. CNPq is also acknowledged for the fellowships to GP and EJL. This study was financed in part by the Coordenação de Aperfeiçoamento de Pessoal de Nível Superior - Brasil (CAPES) - Finance Code 001. 


\section{Supplementary Material}

Copies of ${ }^{1} \mathrm{H},{ }^{13} \mathrm{C}$ and ${ }^{77}$ Se NMR spectra of compounds.

\section{References}

1. Gomtsyan, A. Chem. Heterocycl. Comp. 2012, 48, 7. https://doi.org/10.1007/s10593-012-0960-z

2. Vitaku, E.; Smith, D. T.; Njardarson, J. T. J. Med. Chem. 2014, 57, 10257. https://doi.org/10.1021/im501100b

3. Mahmoud, A. B. A.; Kirsch, G.; Peagle, E. Curr. Org. Synth. 2017, 14, 1091. https://doi.org/10.2174/1570179414666170601121832

4. Xu, W.; Wang, M.; Ma, Z.; Shan, Z.; Li, C.; Wang, H. J. Org. Chem. 2018, 83, 12154. https://doi.org/10.1021/acs.joc.8b02107

5. Oyama, T.; Yang, Y. S.; Matsuo, K.; Yasuda, T. Chem. Commun. 2017, 53, 3814. https://doi.org/10.1039/c7cc01292f

6. Skhiri, A.; Salem, R. B.; Soulé, J. -F.; Doucet, H. ChemCatChem. 2017, 9, 2895. https://doi.org/10.1002/cctc.201700256

7. Arsenyan, P.; Paegle, E.; Domracheva, I.; Gulbe, A.; Kanepe-Lapsa, I.; Shestakova, I. Eur. J. Med. Chem. 2014, 87, 471. https://doi.org/10.1016/i.ejmech.2014.09.088

8. Staples, M. K.; Grange, R. L.; Angus, J. A.; Ziogas, J.; Tan, N. P. H.; Taylor, M. K.; Schiesser, C. H. Org. Biomol. Chem. 2011, 9, 473. https://doi.org/10.1039/c0ob00573h

9. Gao, L. J.; Kovackova, S.; Šála, M.; Ramadori, A. T.; Jonghe S. D.; Herdewijn, P. J. Med. Chem. 2014, 57, 7624.

https://doi.org/10.1021/im5007929

10. Paegle, E.; Domracheva, I.; Turovska, B.; Petrova, M.; Kanepe-Lapsa, I.; Gulbe, A.; Liepinsh, E.; Arsenyan, P. Chem. Asian J. 2016, 11, 1929. https://doi.org/10.1002/asia.201600472

11. Tanini, D.; Panzella, L.; Amorati, R.; Capperucci, A.; Pizzo, E.; Napolitano, A.; Menichetti, S.; d’Ischia, M. Org. Biomol. Chem. 2015, 13, 5757. https://doi.org/10.1039/c5ob00193e

12. Chatterjee, T.; Shetti, V, S.; Sharma, R.; Ravikanth, M. Chem. Rev. 2017, 117, 3254. https://doi.org/10.1021/acs.chemrev.6b00496

13. Zhou, X.; Ai, N.; Guo, Z. -H.; Zhuang, F. -D.; Jiang, Y. -S.; Wang, J. -Y.; Pei, J. Chem. Mater 2015, $27,1815$. https://doi.org/10.1021/acs.chemmater.5b00018

14. Nakano, M.; Mori, H.; Shinamura, S.; Takimiya, K. Chem. Mater 2012, 24, 190. https://doi.org/10.1021/cm202853b

15. Yamamoto, T.; Takimiya, K. J. Am. Chem. Soc. 2007, 129, 2224. https://doi.org/10.1021/ja068429z

16. Takimiya, K.; Kunugi, Y.; Konda, Y.; Ebata, H.; Toyoshima, Y.; Otsubo, T. J. Am. Chem. Soc. 2006, $128,3044$. https://doi.org/10.1021/ja057641k 
17. Schumacher, R. F.; Rosário, A. R.; Leite, M. R.; Zeni, G. Chem.: Eur. J. 2013, 19, 13059.

https://doi.org/10.1002/chem.201302129

18. Rhoden, C. R. B.; Zeni, G. Org. Biomol. Chem. 2011, 9, 1301.

https://doi.org/10.1039/C0OB00557F

19. Staples, M. K.; Grange, R. L.; Angus, J. A.; Ziogas, J.; Tan, N. P. H.; Taylor, M. K.; Schiesser, C. H. Org. Biomol. Chem. 2011, 9, 473.

https://doi.org/10.1039/c0ob00573h

20. Alcaide, B.; Almendros, P.; Busto, E.; Herrera, F.; Lázaro-Milla C.; Luna, A. Adv. Synth. Catal. 2017, 359, 2640.

https://doi.org/10.1002/adsc.201700427

21. Stach, G.; Peglow, T. J.; Roehrs, J. A.; Penteado, F.; Barcellos, T.; Jacob, R. G.; Lenardão, E. J.; Perin, G. Synthesis 2018, 51, 578.

https://doi.org/10.1055/s-0037-1610656

22. Bilheri, F. N.; Pistoia, R. P.; Back, D. F.; Zeni, G. Adv. Synth. Catal. 2017, 359, 4208.

https://doi.org/10.1002/adsc.201701095

23. Sato, T.; Nakamura, I.; Terada, M. Eur. J. Org. Chem. 2009, 5509.

https://doi.org/10.1002/ejoc.200900894

24. Perin, G.; Roehrs, J. A.; Hellwig, P. S.; Stach, G.; Barcellos, T.; Lenardão, E. J.; Jacob, R. G.; Luz, E. Q.

ChemistrySelect 2017, 2, 4561.

https://doi.org/10.1002/slct.201700948

25. Kesharwani, T.; Worlikar, S. A.; Larock, R. C. J. Org. Chem. 2006, 71, 2307.

https://doi.org/10.1021/jo0524268

26. Kesharwani, T.; Giraudy, K. A.; Morgan, J. L.; Kornman, C.; Olaitan, A. D. Tetrahedron Lett. 2017, 58, 638. https://doi.org/10.1016/j.tetlet.2017.01.007

27. Wu, B.; Yoshikai, N. Org. Biomol. Chem. 2016, 14, 5402.

https://doi.org/10.1039/c6ob00219f

28. Paegle, E.; Belyakov, S.; Petrova, M.; Liepinsh, E.; Arsenyan, P. Eur. J. Org. Chem. 2015, 4389. https://doi.org/10.1002/ejoc.201500431

29. Kashiki, T.; Shinamura, S.; Kohara, M.; Miyazaki, E.; Takimiya, K.; Ikeda, M.; Kuwabara, H. Org. Lett. 2009, 11, 2473.

https://doi.org/10.1021/ol900809w

30. Wright, S. W.; Corbett, R. L. Tetrahedron Lett. 1993, 34, 2875.

https://doi.org/10.1016/S0040-4039(00)60469-0

31. Wu, B.; Yoshikai, N. Angew. Chem. Int. Ed. 2013, 52, 10496.

https://doi.org/10.1002/anie.201304546

32. Arsenyan, P.; Vasiljeva, J.; Belyakov, S.; Petrova, M.; Liepinsh, E. Mendeleev Commun. 2016, $26,317$. https://doi.org/10.1016/j.mencom.2016.07.017

33. Mhetre, A. B.; Lee, H.; Yang, H.; Lee, K.; Nam, D. -H.; Lim, D. Org. Biomol. Chem. 2017, 15, 1198. https://doi.org/10.1039/c6ob02729f

34. Sonawane, A. D.; Garud, D. R.; Udagawa, T.; Koketsu, M. Org. Biomol. Chem. 2018, 16, 245. https://doi.org/10.1039/c7ob02523h

35. Peglow, T. J.; Schumacher, R. F.; Cargnelutti, R.; Reis, A. S.; Luchese, C.; Wilhelm, E. A.; Perin, G. Tetrahedron Lett. 2017, 58, 3734.

https://doi.org/10.1016/j.tetlet.2017.08.030 
36. Zang, H.; Sun, J. -G.; Dong, X.; Li, P.; Zhang, B. Adv. Synth. Catal. 2016, 358, 1746. https://doi.org/10.1002/adsc.201501102

37. Sall, D. J.; Bailey, D. L.; Bastian, J. A.; Buben, J. A.; Chirgadze, N. Y.; Clemens-Smith, A. C.; Denney, M. L.; Fisher, M. J.; Giera, D. D.; Gifford-Moore, D. S.; Harper, R. W.; Johnson, L. M.; Klimkowski, V. J.; Kohn, T. J.; Lin, H. -S.; McCowan, J. R.; Palkowitz, A. D.; Richett, M. E.; Smith, G. F.; Snyder, D. W.; Takeuchi, K.; Toth, J. E.; Zhang, M. J. Med. Chem. 2000, 43, 649. https://doi.org/10.1021/jm9903388

38. Barancelli, D. A.; Schumacher, R. F.; Leite, M. R.; Zeni, G. Eur. J. Org. Chem, 2011. 6713. https://doi.org/10.1002/ejoc.201100992

39. Jacob, R. G.; Oliveira, D. H.; Peglow, T. J.; Nascimento, J. E. R.; Bartz, R. H. J. Braz. Chem. Soc. 2019. https://doi.org/10.21577/0103-5053.20190094 